\title{
Matthew Schneirov
}

\section{POPULAR MAGAZINES, NEW LIBERAL DISCOURSE AND AMERICAN DEMOCRACY, 1890s-1914}

The study of the mass circulation "popular magazine" during the Gilded Age and Progressive Era was revived during the 1990s as part of the emerging fields of gender studies, consumer studies, and the study of the new middle class. Richard Ohmann's seminal work viewed these magazines through the lens of the political economy and class relations of an emerging corporate capitalist society and explored the relationship between mass culture and the political economy of capitalism. This paper reexamines the connection between a national mass culture, the new middle class, and an emerging corporate capitalist society through the lens of post-structuralist discourse theory. Corporate capitalism is conceptualized as in part a discourse, the new liberalism, which incorporated or rearticulated populist and socialist discourses and in doing so temporarily won the consent of the capitalist class, middle classes, and segments of the working class. Through the pages of popular magazines readers were offered pieces of a new discourse that embraced corporations rather than the "free market," women's entry into public life, and new constructions of the self. During the muckraking era, elements of socialism and populism were integrated into mainstream American culture. Overall, the essay argues that a discourse perspective on popular magazines can open up new perspectives on corporate capitalism and the new liberalism. While corporate capitalism marked the decline of the producer-republican tradition, it also marked the emergence of an American social democratic tradition, a mixture of capitalist and socialist social formations.

Beginning in 1893, the year of a major economic downturn (the last of a series of crises that began in 1873), the mass circulation, popular magazine emerged in the print media. They were national in readership and, according to recent scholarship on this topic, appealed to a growing new middle class of professionals. ${ }^{1}$ Popular magazines, both the general interest ones like Munsey's, McClure's, and Cosmopolitan as well as the "ladies" and "men's" magazines like Ladies Home Journal (selling over 2 million copies a month) and Saturday Evening Post, made most of their profits from advertising rather than subscriptions and utilized the new half-tone photoengraving that allowed photographs to be used rather than only artwork, dramatically reducing costs. ${ }^{2}$ The new ten cent general interest magazines, Munsey's, McClure's, and Cosmopolitan, led the pack of cheap monthlies in the 1890 s selling close to 1.5 million copies a month between them. They were also the first medium of mass communication that reached a national audience on a regular basis. ${ }^{3}$ Historians and sociologists revived the study of these magazines in the early 1990s as part of the emerging fields of consumer studies, gender studies, and the study of the rise of the new middle class. ${ }^{4}$ 
Richard Ohmann's seminal work on turn of the century popular magazines is the most expansive in viewing these magazines through the lens of the political economy and class relations of an emerging corporate capitalist society and provides the only explicit theoretical explanation linking the rise of mass culture to the political economy of capitalism. Other works, largely in the field of gender studies, are less interested in developing broad historical interpretation or developing a theory of mass culture, but by and large rely on a similar theoretical framework, drawing on the Frankfurt School, Gramsci, and other currents from Western Marxism. Ohmann views this new national media primarily as a route whereby the ruling class of corporate leaders shaped and socialized middle-class consumers. At the same time, Ohmann argues, these magazines expressed the world view of an emerging social class, the professional middle class, who began to assume new roles in reforming, regulating, and managing an economy dominated by these large corporations. For Ohmann, the professional middle class (PMC) was a class in the making, and popular magazines helped their PMC readers negotiate the circumstances in which they lived their lives, providing a "structure of class feeling," helping readers to "chart the social spaces" of homes, stores, streets, and hotels - the "habitus" of middle-class life. On the production side, journalists, publishers, and advertising agencies crafted a cultural product that allowed large corporations access to a national market of consumers. ${ }^{5}$ These magazines adjusted readers to a new political economy and an emerging way of life in a society dominated by large corporations and national advertising.

To be sure, Ohmann rejects the mechanistic Marxist account of the media as a tool of the ruling class. He presents a more sophisticated view in which "hegemony works through media institutions to spread bourgeois ideology and enforce consent." 6 This position does not require conscious manipulation or the use of the media as a propaganda tool, but it does view "mass culture" as a sphere to be colonized by the capitalist class in its project to transform various audiences into markets for consumer goods. Capitalist hegemony works through the transformation of culture into commodities producing a view of the world that is in accord with the everyday experiences of media consumers. This was accomplished through the magazine's self-representation as "general interest" and oriented toward "families," ideological constructions that filtered out salient social and class differences. Mass culture, for Ohmann, was a strategy that helped capitalists to address the multiple crises of the 1880 s and 1890 s - the declining rate of profit of proprietary firms due to multiple depressions or economic downturns as well as workingclass revolts and other forms of social unrest. Through the formation of a national mass culture, capitalists hoped to create consumer demand and thereby "ease the contradictions of late-nineteenth century capitalism."7 Ohmann recognizes that the projects of $\mathrm{PMC}$ readers and editors were not identical to those of capital, and in fact members of the PMC were shaped in their various roles as reformers, in cultural and professional networks, as shapers of mass/consumer culture, and within corporations as managers. ${ }^{8}$ Still, in the final analysis, the PMC acted as agents of capital, as a "historic bloc" with a common worldview.

CORPORATE CAPITALISM AND THE NEW MIDDLE CLASS

I propose in this essay a different approach to connecting popular magazines, arguably the first form of national mass culture, with the transition to a corporate capitalist 
society. The approach offered here focuses on discourse, defined as "particular ways of talking about and understanding the world linked to practices," rather than a class reductionist view or what may be called a "corporate hegemony" approach. A central part of the class-centered or "corporate hegemony" approach views popular magazines as part of the establishment of corporate hegemony that limited or foreclosed more democratic historical possibilities. The victory of corporate capitalism, in this view, was part of a process through which middle-class readers, both men and women, began to see themselves as both consumers and corporate allies, and one in which constructions of femininity and masculinity became increasingly commodified and depoliticized. In contrast I understand corporate capitalism as synonymous with the creation of a new discourse that incorporated elements of labor, populist, and socialist movements, and in doing so opened up new democratic possibilities and social identities. ${ }^{9}$

In a much-quoted passage, Raymond Williams observed that "the area of a culture, it would seem, is usually proportionate to the area of language than to the area of class." 10 Applying Williams' s notion of focusing on "language" in the cultural domain requires rethinking the meaning of two key terms in the dominant narrative of popular magazines_-"corporate capitalism" and the "new middle class." Rather than understanding "capitalism" as a structure that changes according to its own logic or as a backdrop or adversary to the main action-the movements among small producers, workers, and middle-class reformers, corporate capitalism can be conceptualized as both a social movement and a discourse. As a social movement, corporate capitalists (a segment of industrial capitalists) allied with segments of the middle class, intelligentsia, and the working class in order to advance a political program, operating largely outside of the two-party system and using tactics borrowed from other social movements. This occurred in response to the political stalemate of the 1886-1896 years in which the small producer discourse was at least as dominant as the American version of classical liberalism, popularized by Edward Atkinson, E. L. Godkin (editor of The Nation and New York Evening Post), Carl Schurz, George Curtis (editor of Harper's Weekly), and others. $^{11}$

Classical economics, with its belief in the self-regulating market, faced serious critique from academic quarters, political critique from small producers, and growing disenchantment from the general public. Large proprietary firms were dominant in the market, but their hegemony over the state and over culture was contested as Martin Sklar, David Montgomery, James Livingston, and others have shown. ${ }^{12}$ Corporate reformers, facing opposition in the courts and in Congress and growing opposition in public opinion, sidestepped the two-party system and institutional politics in forming a social movement to advance their political program. Their program called for "sound money," a favorable outcome of the anti-trust debates (the Trans-Missouri decision in 1897 eliminated the "rule of reason," potentially making corporations illegal in their pricing power over the market), and control over the work process itself (in relation to the power of skilled workers). While businesses were merging in various ways in the $1880 \mathrm{~s}$ in response to declining profits and prices, the corporate form required far-reaching political, economic, and cultural changes in American society that took two decades or more to accomplish. ${ }^{13}$ The process of achieving dominance was interwoven with the creation of a new discourse - the "new liberalism"- that established hegemony over other competing discourses; market liberalism, populism (or "producer republicanism"); and socialism. ${ }^{14}$ 
The success of corporate capitalism as a hegemonic discourse was only complete with the 1911-14 Supreme Court decisions that reinstated the "rule of reason" for anti-trust cases, the Federal Reserve Act of 1913, and the Clayton Anti-Trust Acts passed in 1914. ${ }^{15}$ These court decisions and laws along with others passed during the earlier years of the Progressive Era made the corporation the center of a new political economy in which the market would remain supreme (over the state), but the government would regulate a corporate-administered market. The "new liberalism," which rearticulated elements of competing political discourses, found its most complete expression in the pages of The New Republic in articles by Herbert Croly, Walter Lippmann, and others. To summarize, corporate capitalism was a political construction, inseparable from the political struggles that created it (in the state, the workplace, and in civil society) and from the discourse that gave it meaning.

Central to the development of what became the hegemonic discourse were elements of the new middle class. But what was the new middle class? How much of an independent political actor was it? In considering how popular magazines intersected with middleclass thinking, feeling, and agency we might consider the meaning of the term "middle class" as well as the more specific "new middle class" and the dangers of treating both as unified wholes as well as the danger of assuming the existence of a class independent of the way it is understood and represented by its members and others. From E. P. Thompson we know that "class" has little meaning abstracted from time and place. For example, the Knights of Labor, during their period of greatest strength, made no distinction between skilled and unskilled workers or between small business owners and artisans and workers. Both were part of the "producing classes." The alliance between the Knights of Labor and the People's Party reflected a larger alliance between elements of the "petit-bourgeoisie" and the working class created by the discourse of "producer-republicanism." 16 What is the salient and relevant category here-a social class category like working class or "petit-bourgeoisie," which did not provide the basis for group unity and political action? Or a language/discourse that in effect created a unity and agency that had a formidable impact, at least until the mid-1890s? In Robert Johnston's work on the "radical middle class," he charts the development of a radical middle-class insurgency in Portland during the first decade of the twentieth century and distinguishes between a "professional elite" that identified with capitalists and a "lower middle class" that included lower-level professionals and small business owners. This distinction, rooted in Progressive Era struggles in Portland, throws into question the unity of the category "professional middle class." 17

These questions highlight the fluidity of class boundaries and the need to examine what these categories meant in a historical context. They also point to the importance of discourse or language in constructing these categories as well as the importance of politics as that arena within which new discourses are created and others challenged. At times we find a common language that unites small business people, workers, and farmers; at other times petit-bourgeois groups and lower-level professionals, and at still other times and places, businessmen, some professionals groups, and segments of the labor movement. These alliances are understood and acted on within the realm of politics in terms of common beliefs, assumptions, and symbols. In all of these cases, culture maps onto the region of language and not class. This principle applies as well to that "class" called the "professional middle class." The perspective here is consistent with 
a post-structuralist reading of Gramsci's concept of hegemony in which discourse is constitutive of social class rather than reflecting it or being determined or shaped by it. ${ }^{18}$

In examining some of the literature on the professional middle class we find that it was, at least during the Gilded Age and Progressive Era, hardly a unified group, and certainly not a group whose members held a common understanding of who they were and what they wanted. For example, we can find the following subgroups among the new middle class with distinct outlooks and discourses who made their mark, directly or indirectly, on popular magazines: professional corporate managers; academics who redefined older fields like economics and established new disciplines like sociology; journalists responsible for magazine muckraking, female professionals in social work, teaching, writing, and nursing whose work in social settlements and in other reform causes received considerable treatment in popular magazines; and those employed in the new advertising agencies whose ads provided magazines with their major source of revenue. ${ }^{19}$ The discourses we discover in reading through the pages of Munsey's, McClure's, or Cosmopolitan connected their readers with other social groups-with Progressive Era movements that were part of the "anti-monopoly" tradition as well as with "new liberal" or "corporate liberal" reform traditions, with the pro-development ("progress") discourse of corporate reformers and with discourses outside the Progressivism entirely, that is market/ mugwump liberalism with its emphasis on cultural uplift, preserving the self-regulating market and the enlightened rule of the "best men." What eventually made the new liberalism hegemonic was that it unified diverse social groups both within the professional middle class and between it and other class factions. In doing so, the new liberalism created a common language that encompassed much of the terrain of political debate. I am suggesting that a social class only becomes visible when segments of that class act politically, and that when they do act politically they invariably act in alliance with other groups. What allows these groups to act together is a discourse that defines mutual interests and a unified subject or actor. In short, "corporate capitalism" was a discourse that united portions of the upper class, middle class, and some working-class supporters (like the emerging AFL) and presented itself as "popular," that is, in accord with popular aspirations. New liberal discourse both incorporated rival discourses and created a "collective will" out of a multiplicity of social viewpoints.

\section{MARKET LIBERALISM IN TRANSITION}

Market liberalism was premised on the principles of classical political economy, that is, the "laws" of the self-regulated market whose principle actors were (white) property holders - both small producers and larger family owned, proprietary firms; it became the central economic philosophy of "proprietary-competitive" capitalism during the Gilded Age. ${ }^{20}$ After the Civil War, a sector within the Republican coalition broke off to oppose increased federal spending to promote economic development and "class legislation" in which the federal government would secure the interest of only some groups but not others. Market liberalism cannot be thought of as an ideology of business interests since many market liberals opposed the protective tariff. ${ }^{21}$ Instead, market liberals were a coalition of some businesses as well as professional associations like the American Social Science Association. ${ }^{22}$ 
The producer-republican discourse was also "liberal" in the sense of being based on the constitutional principle of the supremacy of society over the state, holding with deep suspicion state action that might interfere with the perceived equality of all property holders in the market. But the producer-republican tradition while also supporting the self-regulating market, sought to preserve what Macpherson called a "simple market society," a social vision in which labor was not a commodity; markets existed for products with the small producer predominating in the market. ${ }^{23}$ While dating back to the American Revolution, the producer-republican version of this tradition saw republics as inherently fragile and prone to corruption from those seeking special advantages, especially "wealth seeking minorities." The producing classes—artisans, farmers, small business people - were the wealth producers, and the vitality of the republic required a "republican distribution of wealth," which meant preventing the formation of a permanent class of wage laborers and vast concentration of wealth, two preconditions for industrial capitalism. ${ }^{24}$

Market liberalism differs from the "new liberalism" in two respects. Modern liberalism is based on state and organizational regulation of the market; and secondly, the primary economic actors are groups (associations of capital and labor) rather than the individual property holders. In addition, the new liberalism recognized the dysfunctions of the market, rejecting the doctrine (Say's Law) that supply creates its own demand. ${ }^{25}$ While analytically these discourses can be separated, in the minds of actual people like farmers, workers, artisans, and capitalists, they were often combined. In practice, supporters of market liberalism could worry about the impact of greedy machine bosses and unscrupulous monopolists on the health of the republic, and advocates of producer-republicanism often relied on liberal natural rights language.

With the organizational turn in American industry in response to long-term economic crises and the formation of organizations among workers, farmers, and professionals, market liberalism was already unraveling by the time the first popular magazines were published in $1893 .{ }^{26}$ Twenty years of economic downturns cast doubt on the principles of classical political economy and the self-regulating economy. The growing dominance of organizations by the 1890s reshaped the largely unchallenged view in middle- and upper-class circles of the autonomous (male) economic actor. In other words, the 1890s was a period of transition and struggle between two different languages within which self and society were to be understood, languages that left their trace in the pages of popular magazines. I use the term "discourse" to include both language (like the magazine text) and linkages with the social practices of readers and cultural producers. Popular magazines were connected to the worlds of publishers and editors, journalists, advertising agencies, and businesses. Thus they had ample incentive to represent this struggle between market liberalism with its autonomous male heroes and valorizing of the free market and the new liberal discourse that promoted the values of efficiency and inclusion and revolved around organizations like corporations, professional groups, women's clubs, farmers' associations, and unions.

In addition to organized associations of capital and labor, key to the new liberalism was advertising and more broadly "consumer culture." Labor leaders, feminists, economists, and others associated consumerism with the purchasing power of wage laborers, as well as with opportunities for women to enter the public sphere as consumers in the new department stores, dance halls, and amusement parks, and as consumer activists in the 
dense network of female reform organizations. As Samuel Gompers of the AFL put it, the safeguard against recurring imbalances of supply and demand that brought on a quarter century of depressions was the capacity of the working class to purchase consumer goods (the politics of "more"). ${ }^{27}$ The turn toward consumerism among many labor leaders rested upon the acceptance of the wage labor system, but with it a demand for a higher standard of living (a "living wage") and a shorter working week in order to enjoy the fruits of their labors and fully develop their capacities. This idea of an economy, resting on the consumption of the masses, was conceptualized in terms of a new "social economy." 28

While popular magazines spoke to a largely middle-class audience, the discourse of consumerism, like the new liberalism, crossed class boundaries. Consumers had to be created or socialized; and popular magazines, as a national medium for advertising, played a central role in doing this as early as the 1890s. As Ohmann points out, corporations sought ways to avoid cut-throat price competition by reaching national markets with name brand goods and by addressing their readers as consumers. ${ }^{29}$ Magazines, in their predictable organization of content, formulaic fiction, and the way they educated readers about new products, spoke the language of advertising. This language attracted middle-class women who were becoming shoppers for the home as well as middleclass men navigating the new worlds of college and the corporate career path. ${ }^{30}$ These early magazine ads often reassured readers that they did not have to jettison older cultural ideals rooted in the discourses of market liberalism and producer-republicanism in order to embrace the new. Advertising, in others words, absorbed these older conceptions of masculinity (the self-made man or cultivated man) and femininity (as part of patriarchal households) into the new liberalism of corporate capitalism.

All three of the new general interest magazines during their early years (1893-1897) continued to emphasize cultural preservation, featuring retrospective articles on famous literary and political figures, as well as articles on mugwump reform and, more broadly, articles that highlighted the autonomous (male) self and his possibilities for advancement. ${ }^{31}$ McClure's, from 1893 to 1897 , looked very much like Harper's Monthly or Atlantic Monthly with biographies of Lincoln and Napoleon and fiction from some of well-known authors of the period like Robert Louis Stevenson, Cleveland Moffett, and A. Conan Doyle. ${ }^{32}$ Articles like "Tammany: Early Spoilsmen and the Reign of the Plug-Uglies" (McClure's, 1895) and "Portrait of Robert Louis Stevenson" (McClure's, 1894) could have easily appeared in the family house magazines. ${ }^{33}$ If liberalism "was best represented by its magazines," Harper's Weekly, North American Review, and the Atlantic Monthly, popular magazines were not much of a departure at first. As opponents of party papers, dime novels, story papers, and other forms of commercialized culture and as political reformers seeking to advance a nonpartisan political style and rule by "the best men," mugwump liberal discourse (a variation of market liberalism) also existed as a set of practices. These practices were reinforced by a social network of clubs that shared the "best" of American culture, as well as by political networks like the National League of Republican Clubs and the National Civil Service Reform League that advanced the cause of overturning big city political machines. ${ }^{34}$

There is, though, some evidence that popular magazines, even during their early years, published pieces on and by mugwump intellectuals who began to break from their elitist colleagues. Lyman Gage was the subject of a short biographical sketch in Munsey's in 
1898 after he had led the Chicago Civic Federation and broke from his mugwump past. Gage became a prominent spokesperson for the new liberalism in his capacity with the Chicago Civic Federation, the National Civic Federation, and later as Treasury Secretary. ${ }^{35}$ In addition to Gage, Cosmopolitan published an article by Brooke Adams, which developed the rationale for seeking foreign markets for the "surplus capital" of American industry, an early statement of the analysis by Arthur Hadley and others on the problem of surplus capital and foreign markets, an important element on the new liberal agenda. ${ }^{36}$ Washington Gladden, an early leader in the Social Gospel movement and opponent of the Tweed administration in New York was the subject of a short piece in McClure's (1894). In later years, other magazines would print pieces on the social gospel, which, as Sidney Fine points out, was one of the intellectual sources of the critique of the self-regulating market. ${ }^{37}$

There were more than a few articles on the work of the "new economists," a new generation of economists, largely trained in Germany, who broke with economic orthodoxy. ${ }^{38}$ Richard Ely, founder of the American Economics Association, formed in large part to break with classical economics, was a frequent contributor to both family house and popular monthlies as were many other social scientists and psychologists, including Stanley Hall, Edward Ross, William James, and American Political Science Association President Albert Shaw. Ely contributed five articles for Cosmopolitan in the 1890s on public control of private corporations among other topics. Ely's popular text, Introduction to Political Economy (1889) was originally written for the Chautauqua Library and Scientific Society's required reading program. A new generation of public intellectuals, closely associated with Progressive reform causes, were introduced to the middle-class public in the pages of popular magazines. ${ }^{39}$

Popular magazines extolled the virtues of the "self-made man" while also suggesting that the autonomous male self might not be so autonomous or so rational. Here was another indicator of market liberalism in transition. While the phrase "self-made man" can be dated at least to the early as the 1830s, the new version in the 1890 s almost always centered around the businessman in an industrial setting. ${ }^{40}$ Cosmopolitan's "Captain's of Industry" series presented a genre of magazine biographies that could be found in all the popular monthlies as well as Saturday Evening Post in the late 1890s. In the Cosmopolitan series there were short vignettes of well-known industrialists, inventors, and heads of transportation, financial, and retail empires. The series asked a straightforward question: "How do we explain the great success of this person?" Not surprisingly personal traits like hard work, perseverance, and a good family upbringing played a part in these narratives, much like the tales of earlier genres of the "self-made man." But the writers also mentioned traits that involved more than character and the work ethic, like "great physical power," "prophetic," "masterful," "dominating," and "commanding figure." Perhaps the massive economic empires that these business leaders headed made it difficult to attribute their success to the traits that could be more commonly found in the republican literature of dime novels and the original Horatio Alger tales. The Napoleonic hero was the prototype in all the magazines, a hero whose success depended on more than "reason" and self-denial. Nonrational and extraordinary attributes were clearly implied in the language of these new stories, language that undermined the very moral of the stories - that anyone could achieve the same success if they emulated these heroes. In the Charles Schwab (president of Carnegie Steel in 1897) vignette, 
the editors noted that "he represents the highest development of the salaried employee," a characterization of the new corporate manager and not linked with property ownership. ${ }^{41}$

Quite distinct from the self-made man was the professional man and, to a lesser extent, the professional woman, an "urban type" promoted in the pages of the popular magazines during the same years as they praised the self-made man. Professionalization was one way to assert influence over the market by occupational groups and to promote the reform of institutions like universities, schools, journalism, medicine, the family, and urban life. Implicit in the ideal of professionalization was an effort to assert control over the market for larger social or public purposes. Cosmopolitan led the way in promoting professionalization as a career and as a mode of reform although similar articles could be found in all popular magazines. In 1897, a series of articles explored the campaign, very much on the agenda of Cosmopolitan's publisher, John Brisben Walker, to reform the nation's universities. Walker advocated a fundamental professionalization of the university so that young people would have the education they needed for the coming age of scientific, technological, and organizational progress. University presidents wrote articles in this series on their ideas for reform. ${ }^{42}$ Another in 1902 on "Problems in Education" featured an article by Booker T. Washington on the story of the origins of the Tuskegee Institute. Cosmopolitan ran "Making the Choice of a Profession" in 1903, which explored opportunities for young people in journalism, medicine, law, engineering, and others. ${ }^{41}$ Another series discussed the "professionalization of the home," with Ella Wilcox writing about the "profession of parentage" and Walker inserting himself yet again with "Should Motherhood Be a Profession?"43 A decade later the Ladies Home Journal (LHJ) and its editor Edward Bok advocated bringing Talyorism in the home to increase efficiency and reduce stress, publishing a series of articles that Scanlon argues "struck a chord among readers." 44 The Saturday Evening Post (SEP) as well, carried articles on middle-class careers in medicine and law, among others. ${ }^{45}$ It should be noted here that there was not a simple transition from the "self-made" to the professional man. Both models of selfhood existed in the popular magazine world as new conceptions, like the "organization man" were made consistent with, and to some extent absorbed, older ones. ${ }^{46}$

In the university series Walker brought readers' attention to the reform campaign begun at the Columbian Exposition of 1893 in which Daniel Coit Gilman, first president of Johns Hopkins, gave the opening address at the International Congress on Higher Education convened by the National Education Association. Participants included most of the leading university presidents in the country. ${ }^{47}$ Much of what Gilman advocated can be subsumed under the heading of "professionalization," including higher admissions standards, better libraries and museums, more emphasis on research and specialization, popularizing the work of professors to make it accessible to the general public, and the development of university extension programs to reach the general public, among other suggestions. The modern university, as Eldon Eisenach argues, was one of the key institutions that emerged during this period that laid the basis for challenging the regime of "laissez-faire constitutionalism." 48 The idea of professionalizing the household and motherhood meant bringing scientific knowledge to housewives. It also meant instilling the social ethic of citizenship and service in family relations, and basing the "professionalization" of housework and mothering on shared publicly accessible scientific standards. Eisenach calls the corporation, the new and established professional 
associations, the university, and the new journalism (the nonpartisan national press) "parastate institutions," because they had had taken on aspects of public functions and viewed their role as creating a national community. ${ }^{49}$ The boundary distinguishing the state from civil society had become blurred and increasingly a site of political struggle, a phenomenon Gramsci recognized as a key characteristic of advanced capitalist societies. ${ }^{50}$ Popular magazines began to register this development in their discussions of new professions, professional opportunities in the age of the corporation, and the professionalization of institutions. The professional and the professionalized institution rather than the selfmade man in the market was a foreshadowing of the new liberal discourse, a merging of new organizational developments across social classes. In contrast to much of the literature on the popular magazine, the corporation itself can be understood not as a proprietary firm with enhanced power and capital but as a transitional institution because it professionalized property and made the operation of the firm independent from property.

By 1897, with the onset of the merger wave, magazines more unambiguously embraced economic development in the form of large-scale industries whose products were sold to a national market, along with the scientific and technological innovations that accompanied development. These articles were a departure from the retrospective and regional focus of the family house magazines, centered on East Coast mercantile (rather than manufacturing) culture. In a pre-muckraking article, Ray Stannard Baker described the "movement of wheat," an account of how wheat grown in the Midwest is distributed throughout the country (McClure's 1899). ${ }^{51}$ The 1897 Cosmopolitan series, "Great Business Organizations," explored, as its title implied, the contributions of the new corporations to American progress through their greater efficiency and productivity. A 1898 series in the Cosmopolitan called "Problems of Organization" cheered the organizational direction of American industry with pieces on "Wheat and Its Distribution," "Flour and Flour Milling," and "The Chicago Packing Industry." Munsey's took readers "Behind the Scenes in the Big Stores," to the balls and exclusive clubs in New York frequented by the upper class and provided profiles of "Wall Street," and the "Metropolitan Types" of the "Stockbroker and the "Self-made Man." 52 With their urban setting and fascination with large-scale industry and the new urban upper class, magazines, by 1897 , aligned themselves with an industrializing capitalist society increasingly dominated by large firms and here, in the pre-muckraking era, there was not a hint of criticism of unethical business practices, mistreatment of employees, defrauding consumers, and other topics that would soon appear. In a socialist variation of this theme "Railroads, Cooperation and the Building of States," E. C. Machen began by praising new forms of "practical cooperation and consolidation of endeavors," but also cautioned that "We must be careful not to accumulate recklessly. We need to retain personal ownership-not monopoly of control." By the end of the article, he again cautioned, "the corporation has too often been made the agent of a class exploitation instead of cooperative service. Here is a piece that seems to make the Marxist point that the corporation was a progressive development in principle but could become attached to exploitative and monopolistic relations of production. ${ }^{53}$ "

In addition to economic organization and professional associations, there were occasional articles on labor federations. Munsey's admiration for organization in the economic sphere extended to unions as well with an admiring piece entitled, "The Great Labor Unions and Their Leaders." The article spoke glowingly of labor leaders (of the 
AFL) as a success story and an "achievement as great, in its way, as the work of J. Pierpont Morgan and his associates in the building of giant corporations." 54 This article appeared during the height of the muckraking explosion, in which Munsey's did not participate. Nevertheless, Munsey himself was a member of the National Civic Federation, a leading exponent of the new liberalism and was one of the most generous financial supporters of Roosevelt's Progressive Party in 1912.55 While regarded as apolitical and somewhat of a philistine by many, Munsey clearly supported regulation of the market by both industrial organizations and unions (at least of skilled workers).

Discourse speaks as much through what is not explicitly said as through what is. Market liberalism, with its foundation in classical political economy, is based on the "man of reason," the autonomous economic actor who was also the propertied head of a household. The woman as a "dependent" within the family was politically invisible in the earlier family-based public sphere and invisible as well in an industrializing economy based on "separate spheres." By the late nineteenth century, though, the transformation of the white middle-class households of magazine readers from commodity producing units to locations where commodities were consumed had advanced to a considerable extent as had, the "proletarianization" of skilled workers, artisans, and some small businesses.

During this period as well, single white women entered the labor force and higher education in large numbers. In 1870 women were one-fifth of all college students; in 1880 one-third and in 1900, 37\%.56 Women employed in "white collar" fields like clerks, saleswomen, typists, and bookkeepers increased from $0.8 \%$ in 1870 to $9.1 \%$ in 1910 and in the professions the growth was from $6.4 \%$ in 1870 to $10 \%$ in $1900 .{ }^{57}$ Women reformers established an extensive communications network, their own organizations like settlement houses and a ground swell of female-led reform movements. ${ }^{58}$ In the National Consumers League, The General Federation of Women's Clubs, the American Home Economics Association, and other groups, women became consumer activists and sought to use their financial power as consumers to further the cause of labor reform. Not only middle-class women but immigrant women organized mass protests against price increases, believing that the cost of products needed to maintain their standard of living was a political issue. As Ellen Dubois argues, the political sphere was shifting from one based on an explicitly patriarchal family to the promise, at least, of a public sphere based on individuals. ${ }^{59}$ The gap between this promise and the reality of women's subordination helped spark renewed activism and, according to Linda Nicholson, helps to explain the mass mobilization of women in the suffrage movement during the 1890 s. ${ }^{60}$ It should not be surprising that feminists of this period saw what we would call the processes of proletarianization, a corporate-administered market and the transition out of the household economy as a progressive evolution of society to a more cooperative stage and as one that held promise for women. According to Eisenach,

If any group in American society saw itself as enthusiastically committed to modernization and economic development along Progressive lines, it was the new feminist intellectuals. Indeed, they and the new political economists were the first to recognize and integrate the woman question and issues of family life into economic analysis-women who had been invisible in classical economic theory as they were in classical liberal political theory. Most of the leading women Progressives who wrote on economic topics did so in the journals and through the organizational networks 
founded and run by these economists. And when these women wrote in popular magazines, they shared the same venues and usually the same values as these economists. ${ }^{61}$

While magazines differed in their editorial stance on questions like suffrage, women working outside the home, and other issues, in various ways they all opened their pages to exploring the entry of women into public life and broader changes for women in the family. Prior to Edward Bok's reign as editor of the $L H J$, in the 1880s, Louisa Knapp Curtis saw women's new position as consumers in the family as a step toward greater autonomy and sought to provide a forum for women "to understand their lives in relation to men." Damon Moore characterizes this early period as one in which the magazine took "advanced and flexible positions with regard to women's expanding activity." 62 Cosmopolitan followed Knapp's lead in the Walker years in attending to how the larger changes in society and women's participation in the public sphere affected marriage and family life in general. While the patriarchal family as a basis for the public sphere was being replaced with an individual-based public sphere, at the same time family life itself was becoming more individuated. Of course, this does not mean that anything approaching gender equality existed, but, in various nonfiction pieces and especially in their fiction, LHJ, Cosmopolitan, and other magazines characterized marriage and parenting as in flux and, in part, open to public examination. How to encourage better marital communication, how to prepare children for careers but not become too demanding, how fathers could treat parenting as a profession, how to handle the "loss of ideals" after the original glow of marriage fade, all were topics explored in these articles. A serial story, "The Other Woman," published in Cosmopolitan in 1909, is about a woman who discovers that her divorce lawyer-husband is having a romantic engagement with one of his clients. The "other woman" is characterized as feeling bored and needing some excitement. Normally these stories would conclude with a happy ending, but in this case, the wife confronts her husband and then decides to stay in a loveless marriage because she is pregnant with her second child. Though she stays with her husband for the sake of her children, this is clearly not a happy ending. Her sacrifice, while presented as noble, must have struck female readers as a much more ambiguous outcome. No doubt some of this was inspired by the rising divorce rate, but the theme of female discontent with marriage was hardly disguised. ${ }^{63}$

While Edward Bok, as the new editor of $L H J$, beginning in 1890, was an opponent of feminism and women's suffrage, articles were printed that departed from the editor's preferences. Moreover, the desire to position the readers of the Journal as upscale consumers in order to increase revenue encouraged Bok to take a less traditionalist stance. His opposition to women's clubs aroused such opposition among his readers that he had to provide ample space for the opposing view. ${ }^{64}$ In 1909, during the magazine muckraking era, staff members for the National Consumer's League wrote a muckraking series in $L H J$, "Why Working Girls Fall Into Temptation," which advocated for higher pay for working women. In 1910, Ida Tarbell discussed "Man's Inhumanity to Women," in American and Edith Wyatt contributed a piece to McClure's in 1911 on "Working Girls Budgets." 65

Embracing corporations, the new professionalism, women's entry into public life, and introducing readers to critics of the self-regulating market, popular magazines provided readers with pieces of a new view of the world and new constructions of the self or new 
subjectivities while simultaneously preserving and transforming elements of older constructions like the self-made man. In this new view, the corporation-not the marketwas the center of American life, an institution in which ownership and control had become partially socialized and therefore open to public scrutiny. With the entry of single women into the labor force and the individuation of family relations (an expression of the decline or transformation of the patriarchal family), both topics became objects of examination in magazines. At the base of this new order was no longer the autonomous male individual, but organized social life, a civil society closely interconnected with the state in the form of institutions like the family, the press, and the university redesigned for public purposes. ${ }^{66}$ The new post-propertied individual included both women and men and promoted social movements among which were feminism and environmentalism.

MUCKRAKING: $1901-1912$

Recent work on popular magazines virtually ignores the most significant genre: magazine muckraking. Perhaps the reason for this omission is that the entire genre from its earliest precursors in 1899 to the last muckraking publications in 1912 challenges the dominant paradigm of most scholars. Muckraking either has to be ignored or explained away as reformist and ultimately supportive of "capitalism." 67 But muckraking topics spanned the broad array of upper-class, middle-class, and (to a lesser extent) workingclass reform, solidifying a new liberal discourse that had begun in the 1890s and that integrated elements of both socialism and the anti-monopoly tradition (populism) into mainstream American culture. Muckraking appeared in the only medium that had a national audience and one that tied together diverse reform campaigns and communities, providing a common language within which to understand diverse struggles and campaigns.

The confluence of the politicization of the trust question between 1897 and 1911 in which the legality of the corporation was not a certainty, the height of the socialist movement, and the Roosevelt administration's close links to magazine publishers and journalists are all reasons this genre took off when it did. What was also important was the influence of the Hearst and Pulitzer newspaper empires that developed the "sensational" style of journalism as well as a core of experienced journalists immersed in reform and socialist networks. ${ }^{68}$ The success of popular magazines and the accompanying financial resources of magazine publishers was also a factor since muckraking required a large research budget and as muckraking journalists acquired a national reputation, they too commanded large salaries. ${ }^{69}$ Hearst brought many of these journalists with him when he bought John Brisben Walker's Cosmopolitan but many radical journalists, like Charles Edward Russell, had no trouble finding work at other magazines as well. The central muckraking themes of mobilizing public opinion to combat corporate corruption of public life and more broadly the corruption of social institutions, like churches, newspapers, unions, and universities resonated with a middle-class public that had heard about reform campaigns in their localities and could, for the first time, tie these campaigns to a larger national narrative. ${ }^{70}$

McClure's, Cosmopolitan, Everybody's, Colliers, The Era, The Arena, Success, Ladies Home Journal, Leslies, Hampton's, World's Work, Woman's Home Companion, and Review of Reviews all participated in the magazine muckraking phenomenon, many 
of them extensively and many of the articles in these magazines were closely connected to reform movements, either emerging out of reform campaigns or actually generating them. ${ }^{71}$ Many muckraking series extended over many months in multiple magazines seeking to galvanize public opinion for reform legislation. Many of the muckrakers wrote best-selling books based on these articles and more than a few sparked congressional investigations or hearings on the state level. Muckraking and Progressive Era reform were inextricably connected, as were the muckrakers and the Roosevelt administration. Roosevelt himself said on at least one occasion that he was an avid magazine reader and used the magazines to gauge public opinion. ${ }^{72}$ For many of these magazines (like the Everybody's series "Frenzied Finance"), circulations shot up after introducing muckraking series, although not all muckraking pieces had an upward effect on circulation. ${ }^{73}$ Given the number of muckraking publications it's safe to say that tens of millions of people were immersing themselves in these issues on a regular basis.

It is true that of the four highest circulation magazines during the 1903-1910 period, two of them, Munsey's and SEP, carried little muckraking and were explicitly critical of the muckrakers. Still, both publications in their editorial policy enthusiastically supported Roosevelt and the New Nationalism and the Post carried numerous articles arguing for government regulation of the "trusts," criticizing conservative domination of the U.S. Senate, and the need for corporations to be accountable to the public. ${ }^{74} \mathrm{~A}$ 1906 SEP article by Alfred Henry Lewis on "The New Young Man," was an effort to refute claims that in the age of the corporation, social mobility for the middle class was limited. Lewis's examples, though, of the new success story in the corporate age were all corporate managers, professionals, and political reformers (not businessmen), a message certainly consistent with muckraking. It seems that both Munsey's and SEP objected more to the strident and personal tone of muckraking rather than the substance. ${ }^{75}$

Muckraking could take the form of defending the competitive market against monopolists. Ida Tarbell's famous series on Standard Oil can be read that way, with her idyllic descriptions of the early days of the oil industry in Pennsylvania in which a vital and healthy individualism was destroyed by the unscrupulous business methods of Rockefeller's Standard Oil. ${ }^{76}$ She advocated federal regulation of the transportation industry primarily to prevent monopolies and create competitive markets. Burton J. Hendrick in "Great American Fortunes and Their Making" and other work exposed corporate corruption in New York City municipal utilities, insurance, and the railroad industry, among others. ${ }^{77}$ Like Tarbell, he wanted to restore the competitive market through state and federal regulation and through an enlightened and activated citizenry. Most of the other muckrakers, though, supported the corporate form but wanted federal regulation of corporations or, for some, nationalization of industries like the railroads.

Lincoln Steffens in "Shame of the Cities" delineated a national pattern of urban corruption. ${ }^{78}$ Near the end of the series, Steffens focused on Chicago as a model of effective reform, highlighting the efforts of corporate reformer Lyman Gage, who in 1895, became the first president of the Chicago Civic Federation (later the National Civic Federation), a leading vehicle for corporate reformers, Progressives, labor leaders, and others to advance the new liberal agenda. Steffens never joined the Socialist Party, but was friends with virtually all the leadership, including Eugene Debs who repeatedly urged him to join. But Steffens, like many other muckrakers, was more comfortable with the 
non-statist, non-doctrinaire socialism that was already emerging within American institutions. Steffens advocated democratic control on the part of shareholders of corporations, a form of economic democracy and, like many of the other left-leaning journalists, was a strong advocate of the social gospel (Stephens developed his own version). ${ }^{79}$ Steffens had a lifelong friendship with Edward Filene, a major retailer of women's ready-made clothing and innovator in marketing discount goods, who was also a reformer who believed that "mass consumption was the twentieth century version of socialism." 80 A supporter of populism and Henry George in the 1880s, Charles Edward Russell by the 1890s was a prominent journalist for the Hearst newspaper empire, joining with Hearst to found the Chicago American newspaper. He wrote the influential exposes of the "beef trust" for Hearst's Cosmopolitan and Everybody's and also wrote exposes of Trinity Church and prison conditions for other publications. Russell joined the Socialist Party in 1908 and ran for public office as a socialist and was one of the founders of the NAACP. ${ }^{81}$ Ray Stannard Baker also moved closer to socialist ideas during the muckraking era having modified his older faith in the competitive market and opposition to all "trusts," whether they took the form of national unions or corporations. Like other muckrakers he was attracted to the Socialist Party's ethic of solidarity and brotherhood (as well as the social gospel) and as an "antidote to the excesses of (economic) individualism." 82

Hearst was the most prominent publisher in bringing a core of radical journalists to national attention, including prominent members of the Socialist Party (regarded by some as part of the center-right wing of the party). At the same time, there were a range of voices, all critical of "trusts" but some critical of the Socialist Party, then at its electoral height, and others supporting a restoration of the competitive market and rugged individualism. Various authors exposed the horrors of child labor (Edward Markham's Hoe-Man in the Making), nefarious plutocrats (Alfred Henry Lewis's on Andrew Carnegie) and the corruption of the U.S. Senate by business interests (David Graham Phillip's Treason of the Senate). ${ }^{83}$ Markham's popular series on child labor drew heavily on the work of the social settlements, progressive activists in the anti-child labor movement, social science data, and social gospel theology. The article, like much of muckraking, nationalized movements that had been focused largely on the municipal and state levels. Jack London and Josiah Flynt (author of True Stories from the Underworld) wrote first-hand accounts of the urban cultures of the race track and pool room while London explored his experiences as a hobo and his encounters with the police and prison systems. ${ }^{84}$

Muckraking was a distinctive journalistic genre that interwove anti-monopoly and socialist themes within the liberal constitutional tradition. In this sense "socialism" refers to both organized socialism as well as what Daniel Rodgers calls "the language of social bonds," a language that could be found in the pre-muckraking magazine period as well. ${ }^{85}$ These strands were tied together by the emphasis on corporate corruption (the "plutocracy"), the corruption of all institutions by private interests, and by the faith in an educated and enlightened citizenry ("public opinion") that had the capacity to extend and deepen the American democratic tradition. To the muckrakers, democracy had to adapt to new economic circumstances (the corporation) and could no longer be tied to corrupt parties and courts that protected a regime of "laissez-faire constitutionalism" and a Congress (mainly the Senate) bought off by business interests. What the new 
economic or "industrial democracy" would look like was rarely discussed in any depth, but it was clear that the muckrakers sought a new political regime. This new regime would require not only political but broad-based institutional change. The old regime of "parties and courts" that supported the competitive market would only change from within, spurred by a coalition of the national nonpartisan press in close alliance with social gospel ministers, reform-minded academics in the universities, skilled workers in the AFL, corporate reformers, and by 1901 a sometimes ally in the White House.

\section{CONCLUSION}

Theodore Greene, one of the few scholars who has discussed muckraking in the context of the entire period between 1893 and 1914, sees a fundamental shift from the 1890s, in which the "Napoleonic hero" predominated to the social reform period of the early twentieth century, a period dominated by muckraking and heroes who were not industrialists but social reformers. ${ }^{86}$ In one sense, Greene is certainly right to observe a radical shift in tone between these two periods. But when we look at more than magazine biographies (Greene focused only on these), we can find continuity as well. Magazines in the 1890s carried on, for a period, the mugwump reform tradition of their predecessors and the "trust question" would not be leading the agenda of national politics until the late 1890s. At the same time, popular magazines gave voice to a cross-class perspective that sought an alternative to both market liberalism and "economic man," a voice that was hardly new and unique to these magazines but, given their national middle-class readership, spoke with some authority. Magazine muckraking brought the language of radical reform politics into the mainstream of middle-class culture and crystallized strands that had been present earlier in popular magazines, though not expressed as consistently or cogently. The abuses of the competitive market and the political environment within which it operated was the subject of muckraking outrage providing energy for a reform-oriented language that sought solutions to social conflict and ethical abuses such as child labor, urban poverty, and consumer fraud that could only be addressed through new forms of economic and social "cooperation."

In order to avoid reductionist approaches in which, however nuanced, culture is an expression of the economic base, we need to shift our understanding of a concept that has been central to much of the scholarship on the popular magazine: "hegemony." If we understand "hegemony" in light of the work of Stuart Hall, as well as Ernesto Laclau and Chantal Mouffe, then hegemony does not refer to the imposition of capitalist control or co-optation (let alone defeat) of more "radical" anticapitalist forces, but rather the temporary winning of popular consent through an alliance between segments of the capitalist class, middle classes, and subaltern classes (each hegemonic formation will create its own alliances), and the creation of a new "collective will." In Laclau and Mouffe's reworking of Gramsci, the establishment of hegemony is synonymous with one discourse incorporating or "rearticulating" aspects of other discourses in order to create a new language that eventually becomes a new common sense. In this perspective capitalists are not inherently reactionary or progressive. ${ }^{87}$ That depends on the nature of the hegemonic formation, that is, the alliances formed and the discourse that becomes the dominant one. In this sense the hegemony of new liberal discourse refers both to the successful multiclass alliance between segments of the capitalist class and other classes in 
establishing a new political economy as well as the incorporation of elements of populism and socialism into a new discourse. The leadership of capitalists (or at least a wing of the capitalist class) in society and (along with elements of the middle class) in the new medium of popular magazines expressed itself in the ability of capitalists and their allies to make their program popular, to make a convincing case that the state-regulated and consumer-oriented corporation was in the interest of diverse groups. The central role of the popular magazine in advancing national advertising and consumer culture was far from "depoliticizing," as Lawrence Glickman, Kathy Peiss, Meg Jacobs, and others have shown. ${ }^{88}$ Instead consumer culture, like the new liberalism, provided a language that unified diverse social groups in its emphasis on a rising standard of living, the politics of everyday life, and new public roles for women as consumers and activists. The commodification of the home, a central factor in the development of national name brand advertising, far from depoliticizing women's lives, helped to spark widespread consumer activism on behalf of middle-class and working-class women.

Richard Ohmann's work, as well as much of the work on magazines in the gender studies and consumer studies traditions, at least implicitly buys into the sense of loss that has characterized much of the writing on the Progressive Era. This view understands the victory of corporate capitalism over both populism and the Knights of Labor as a disaster for American democracy. In this essay, I have tried to show what may be learned from viewing the age of corporate capitalism not only as a loss of what might have been but as a positive gain. Such a shift in perspective may also widen the lens through which we view the evidence-allowing us to notice the emergence of a new language of social individualism in the 1890s and the importance of muckraking during the early twentieth century. The age of "corporate capitalism" or organized capitalism marked the end of any real challenge of the producer-republican tradition to corporate capitalist hegemony and also marked the declining influence of the Socialist Party. But at the same time it ushered in a new age of regulated markets, consumer identities, and organized group interests that sought to insert social values into the private sphere of the market. In other words, what emerged from the rise of corporate capitalism was an American version of social democracy or at least the seeds of a social democracy that would develop further a few decades later. A social democracy existed not only in the form of state redistributive and regulatory activities but in the corporation itself, its public character, and its social welfare functions; it existed in the expanding realm of social movements, nonprofit and professional organizations, and trade unions that expanded their membership close to tenfold from the late $1890 \mathrm{~s}$ to 1910 ; and it existed in farmers' co-ops, municipal ownership of utilities, and the expansion of public school systems. Social democracy was, in Martin Sklar's terms, a mix between capitalist and socialist social formations, a deepening and enriching of American democracy. ${ }^{89}$

\section{NOTES}

${ }^{1}$ This paper draws on my book on popular magazines but provides a theoretical framework missing in that book and engages with subsequent work (since 1994). There is also some new empirical material in this paper. 
The Dream of a New Social Order: Popular Magazines in America, 1893-1914 (New York: Columbia University Press, 1994).

${ }^{2}$ See Frank Luther Mott, A History of American Magazines, 1865-1905, vol. 4 (London: Harvard University Press, 1957), 44-56; Theodore Peterson, Magazines in the Twentieth Century (Urbana: University of Illinois Press, 1975), 1-17; Neil Harris, "Iconography and Intellectual History: The Half-Tone Effect" in New Directions in Intellectual History, eds. John Higham, Paul Conklin, and Neil Harris (Baltimore: Johns Hopkins University Press, 1979), 196-211.

${ }^{3}$ On popular magazine circulation, see Mott, A History of American Magazines, 1865-1905, vol. 4, 15-20; Theodore P. Greene, America's Heroes: The Changing Models of Success in American Magazines (New York: Oxford University Press, 1970), 174. Ohmann argues that these magazines were the first medium of mass communication that reached a national audience on a regular basis. See Richard Ohmann, Selling Culture: Magazines, Markets, and Class at the Turn of the Century (London: Verso, 1996), 11-30.

${ }^{4}$ Among the books on popular magazines during the 1990s were Jan Cohn, Creating America: George Horace Lorimer and The Saturday Evening Post (Pittsburgh, PA: University of Pittsburgh Press, 1989); Ellen Gruber Garvey, The Adman in the Parlor: Magazines and the Gendering of Consumer Culture, 1880's to 1910's (New York: Oxford University Press, 1996); Jennifer Scanlon, Inarticulate Longings: The Ladies Home Journal, Gender and the Promises of Consumer Culture (New York: Routledge, 1995); Helen Damon-Moore, Magazines for the Millions: Gender and Commerce in the Ladies' Home Journal and the Saturday Evening Post (New York: SUNY Press, 1994); Matthew Schneirov, The Dream of a New Social Order; and Richard Ohmann, Selling Culture. Two more recent books break, at least in part, from the framework developed in the 1990s: Daniel A. Clark, Creating the College Man: American Middle Class Magazines and Middle-Class Manhood (Madison: University of Wisconsin Press, 2010); and Tom Pendergast, Creating the Modern Man: American Magazines and Consumer Culture, 1900-1950 (Columbia: University of Missouri Press, 2000).

${ }^{5}$ Ohmann, Selling Culture, 149-60.

${ }^{6}$ Ohmann, Selling Culture, 46.

${ }^{7}$ Ohmann, Selling Culture, 59.

${ }^{8}$ Ohmann, Selling Culture, 344-45.

${ }^{9}$ This definition of discourse draws on Marianne Jorgensen and Louise Phillips, Discourse as Theory and Method (Los Angeles: Sage, 2002), ch. 1; and more broadly, Ernesto Laclau and Chantal Mouffe, Hegemony and Social Strategy: Towards a Radical Democratic Politics (London: Verso, 1985). On the linking of corporate hegemony and new constructions of masculinity and femininity, see Helen Damon-Moore, Magazines for the Millions: Gender and Commerce in the Ladies Home Journal and the Saturday Evening Post, 1880-1901, 155-88. On the two schools of historians that see corporate capitalism through the lens of "a sense of loss" and an emerging school that views consumer culture and corporate capitalism as compelling "new considerations of selfhood, politics, and social organization," see Rosanne Currarino, The Labor Question in America: Economic Democracy in the Gilded Age (Urbana: University of Illinois Press, 2011), 6-9.

${ }^{10}$ Raymond Williams, Culture and Society (New York: Columbia University Press, 1958), 340.

${ }^{11}$ On the political stalemate of the 1886-1896 years, see James Livingston, The Origins of the Federal Reserve System: Money, Class, and Corporate Capitalism, 1890-1913 (Ithaca, NY: Cornell University Press, 1986), 33-48; and James Livingston, "The Social Analysis of Economic History and Theory: Conjectures on Late-Nineteenth Century American Development," American Historical Review 92 (Feb. 1987): 69-95.

${ }^{12}$ Martin Sklar, The Corporate Reconstruction of American Capitalism, 1890-1916: The Market, Law, and Politics (Cambridge, UK: Cambridge University Press, 1988), 20-40; David Montgomery, The Fall of the House of Labor, 1865-1925 (Cambridge, UK: Cambridge University Press, 1988); James Livingston, Pragmatism and the Political Economy of Cultural Revolution, 1850-1940 (Chapel Hill: University of North Carolina Press, 1994), 45-49, 84-100; Leon Fink, "The New Labor History and the Powers of Historical Pessimism: Consensus, Hegemony, and the Case of the Knights of Labor," Journal of American History 75:1 (June 1988): 115-36; John Jentz and Richard Schneirov, Chicago in the Age of Capital: Class, Politics, and Democracy during the Civil War and Reconstruction (Urbana: University of Illinois Press, 2012), 173-75, 182-83, 192-95, 244-45.

${ }^{13}$ Livingston, Origins of the Federal Reserve System, chs. 3 and 4.

14“New liberalism" is a term developed by Mary O. Furner and Michael J. Lacey in The State and Social Investigation in Britain and the United States (New York: Cambridge University Press, 1993). The "new liberalism" is similar to Martin Sklar's "corporate liberalism." 
${ }^{15}$ Martin Sklar, The Corporate Reconstruction of American Capitalism, chs. 3 and 4.

${ }^{16}$ Leon Fink, Workingmen's Democracy: The Knights of Labor and American Politics (Urbana University of Illinois Press, 1983), 3-17; James L. Huston, "The American Revolutionaries, the Political Economy of Aristocracy, and the American Concept of the Distribution of Wealth, 1765-1900," American Historical Review 98 (Oct. 1993): 1079-1105; Richard Schneirov, "Thoughts on Periodizing the Gilded Age: Capital Accumulation, Society and Politics, 1873-1898," Journal of the Gilded Age and Progressive Era 5:3 (July 2006): 189-224; Roseanne Currarino, The Labor Question in America: Economic Democracy in the Gilded Age, 13-14, 118.

${ }^{17}$ Robert D. Johnston, The Radical Middle Class: Populist Democracy and the Question of Capitalism in Progressive Era Portland, Oregon (Princeton, NJ: Princeton University Press, 2003), 3-17. On the formation of the professional middle class during the Gilded Age and Progressive Era, see Robert Wiebe, The Search for Order, 1870-1920 (New York: Hill and Wang, 1967), ch. 5; and Stuart M. Blumin, The Emergence of the Middle Class: Social Experience in the American City, 1760-1900 (Cambridge, UK: Cambridge University Press, 1989). For a sociological treatment with an emphasis on Marxist and neo-Marxist approaches, see Pat Walker (ed.), Between Labor and Capital: The Professional Managerial Class (Boston: South End Press, 1979).

${ }^{18}$ Laclau and Mouffe, Hegemony and Social Strategy, 91-100.

${ }^{19}$ Thomas Haskell, The Emergence of Professional Social Science: The American Social Science Association and the Nineteenth-Century Crisis of Authority (Baltimore: Johns Hopkins University Press, 1977); Alfred D. Chandler, The Visible Hand: The Managerial Revolution in American Business (London: Belknap Press, 1977), 377-500; Allen F. Davis, Spearheads for Reform: The Social Settlements and the Progressive Movement, 1890-1914 (New Brunswick, NJ: Rutgers University Press, 1977); Olivier Zunz, Making America Corporate, 1879-1920 (Chicago: University of Chicago Press, 1990), 9-10; 39-40; 45-46.

${ }^{20}$ A clear discussion of corporate liberalism or what others call the "new liberalism" can be found in Carl P. Parrini and Martin J. Sklar, "New Thinking about the Market, 1896-1904: Some American Economists on Investment and the Theory of Surplus Value." The Journal of Economic History 43:3 (Sept. 1983): 559-78.

${ }^{21}$ David Montgomery, Beyond Equality: Labor and the Radical Republicans, 1862-72 (Urbana: University of Illinois Press, 1967).

${ }^{22}$ Richard Schneirov, Labor and Urban Politics: Class Conflict and the Origins of Modern Liberalism (Urbana: University of Illinois Press, 1998), 60.

${ }^{23}$ C. B. Macpherson, The Political Theory of Possessive Individualism: Hobbes to Locke (New York: Oxford University Press, 1962).

${ }^{24}$ James Huston, "The American Revolutionaries, the Political Economy of Aristocracy, and the American Concept of the Distribution of Wealth, 1765-1900," American Historical Review 98 (Oct. 1993): 1079-1105.

${ }^{25}$ Martin J. Sklar, "New Thinking about the Market, 559-78."

${ }^{26}$ Rosanne Currarino discusses the effort in popular literature to save the self-reliant property-holding individual during the 1890s. See The Labor Question in America, 135-39.

${ }^{27}$ See Currarino, The Labor Question, 86-113; and Lawrence B. Glickman, A Living Wage: American Workers and the Making of Consumer Society (Ithaca, NY: Cornell University Press, 1997), 60.

${ }^{28}$ Glickman, A Living Wage, 57-77.

${ }^{29}$ Ohmann, Selling Culture, 81-117.

${ }^{30}$ Christopher P. Wilson, "The Rhetoric of Consumption: Mass-Market Magazines and the Demise of the Gentile Reader, 1880-1920" in Richard Wightman Fox and T. J. Lears, eds., The Culture of Consumption: Critical Essays in American History, 1880-1980, 39-64. On middle-class men navigating the world of college and the corporate career path, see Daniel Clark, Creating the College Man.

${ }^{31}$ On mugwump reform, see John G. Sproat, "The Best Men” Liberal Reformers in the Progressive Age (New York: Oxford University Press, 1968); Gerald W. McFarland, Mugwumps, Morals and Politics: 1884-1920 (Amherst: University of Massachusetts Press, 1975); Richard Schneirov, Labor and Urban Politics, 60-63; Matthew Schneirov, The Dream of a New Social Order, 27-28, 34-35, 112-13, 117-18; Stephen Skowronek, Building the New American State: The Expansion of National Administrative Capacities, 1877-1920 (Cambridge, UK: Cambridge University Press, 1982), 133-38. On the autonomous male self and possibilities for advancement, see Theodore Greene, America's Heroes, 110-65; Daniel A. Clark, Creating the College Man, 26-47.

${ }^{32}$ Peter Lyon, Success Story: The Life and Times of S.S. McClure (New York: Charles Scribner's Sons, 1963), 113-33; Harold S. Wilson, McClure's Magazine and the Muckrakers (Princeton, NJ: Princeton University Press, 1970), 62-80; Frank Luther Mott, A History of American Magazines, vol. 4, 589-607. 
${ }^{33}$ Matthew Schneirov, The Dream of a New Social Order, 75-85.

${ }^{34}$ Michael E. McGeer, The Decline of Popular Politics (New York: Oxford University Press, 1986), 80-81.

${ }^{35}$ Theodore Greene, America's Heroes, 110-65; Daniel A. Clark, Creating the College Man, 26-47.

${ }^{36}$ Brooks Adams, McClure's 12 (April 1899): 558.

${ }^{37}$ Sidney Fine, Laissez. Faire and the General-Welfare State: A Study of Conflict in American Thought, 1865-1901 (Ann Arbor: University of Michigan Press, 1967), 170-71.

${ }^{38}$ On the "new economics," see Carl P. Parrini and Martin J. Sklar, "New Thinking About the Market, 18961904: Some American Economists on Investment and the Theory of Surplus Capital"; James Livingston, "The Social Analysis of Economic History and Theory: Conjectures on Late Nineteenth-Century American Development," 76-80; Roseanne Currarino, The Labor Question in America, 63-85; Michael J. Lacey and Mary O. Furner, The State and Social Investigation in Britain and the United States, 177-97; Dorothy Ross, The Origins of American Social Science (Cambridge, UK: Cambridge University Press, 1991), 172-218; Daniel T. Rogers, Atlantic Crossings: Social Politics in a Progressive Age (Cambridge, MA: Belknap Press, 1998), 97-111.

${ }^{39}$ Richard F. Teichgraebber, Building Culture: Studies in the Intellectual History of Industrializing America, 1867-1910 (Columbia: University of South Carolina Press, 2010), 80, 85-87, 99, 105.

${ }^{40}$ John G. Cawelti, Apostles of the Self-Made Man: Changing Concepts of Success in America (Chicago: University of Chicago Press, 1965); Irvin G. Wyllie, The Self-Made Man in America (New Brunswick, NU: Free Press, 1954).

${ }^{41}$ Cosmopolitan 33 (July 1902): 284-86; Daniel A. Clark, Creating the College Man, 30.

${ }^{42}$ The Cosmopolitan series, "Modern College Education: Does It Educate in the Broadest Sense of the Term?" began in April 1897 with an introduction by Walker followed in May by an article by Daniel Cott Gilman, president of Johns Hopkins University. On the university reform movement, see Teichgraebber, Building Culture: Studies in the Intellectual History of Industrializing America, 75-109.

Walker's series, "Making the Choice of a Profession" ran through 1903. Also see Theodore Greene, America's Heroes, 97; Matthew Schneirov, The Dream of a New Social Order, 96. On the link between college and the professions as a theme in popular magazines, see Daniel A. Clark, Creating the College Man.

${ }^{43}$ Ella Wheeler Wilcox, "Parenthood," Cosmopolitan 32 (Dec. 1901): 175; John Brisben Walker, "On the Choice of a Profession-Motherhood," Cosmopolitan 25 (May 1898): 89.

${ }^{44}$ Jennifer Scanlon, Inarticulate Longings, 64.

${ }^{45}$ Theodore Greene, America's Heroes, 185.

${ }^{46}$ See Daniel Clark, Creating the College Man who argues that college, as depicted in popular magazines, maintained older ideals of masculinity even while advancing newer ones-character as well as otherdirectedness.

${ }^{47}$ Cosmopolitan (May 1897).

${ }^{48}$ Eldon J. Eisenach, The Lost Promise of Progressivism (Lawrence: University Press of Kansas, 1994), 12-13; 259-60.

${ }^{49}$ Eldon J. Eisenach, The Lost Promise of Progressivism, 134-37.

${ }^{50}$ Joseph A. Buttigieg, "The Contemporary Discourse on Civil Society," Boundary 32:1 (Spring 2005): 33-52; James Livingston, Pragmatism, Feminism and Democracy: Rethinking the Politics of American History (New York: Routledge, 2001), 54-55.

${ }^{51}$ Ray Stannard Baker, “The Movement of Wheat," McClure's 8 (Nov. 1899): 124.

${ }^{52}$ Munsey's, vol. 21, 278, 415.

${ }^{53}$ E. C. Machen, "Railroads and the Building of States" Cosmopolitan 32 (Jan. 1902).

${ }^{54}$ Guy Warfield, “The Great Labor Unions and Their Leaders," Munsey's 31(June 1904): 358-65.

${ }^{55}$ James Weinstein, The Corporate Ideal in the Liberal State (Boston: Farrar Straus and Giroux, 1968), 154-55.

${ }^{56}$ Rosalind Rosenberg, Beyond Separate Spheres: Intellectual Roots of Modern Feminism (New Haven, CT: Yale University Press, 1982), 54-83; Carol Smith Rosenberg, Disorderly Conduct: Visions of Gender in Victorian America (New York: Oxford University Press, 1985), 245-96.

${ }^{57}$ Elizabeth Ammons, "The New Woman as Cultural Symbol and Social Reality" Six Women Writers' Perspectives" in Adele Heller and Lois Rudnick (eds.), 1915 The Cultural Moment: The New Politics, The New Woman, The New Psychology, and the New Theatre in America (New Brunswick, NJ: Rutgers University Press, 1991), 82. 
${ }^{58}$ Theda Skocpol, Protecting Soldiers and Mothers: The Political Origins of Social Policy in the United States (New York: Belknap Press, 1992).

${ }^{59}$ Ellen Dubois, "Radicalism of the Woman's Suffrage Movement" in Anne Phillips, ed., Feminism and Equality (New York: NYU Press, 1987), 127-38.

${ }^{60}$ Linda J. Nicolson, Gender and History: The Limits of Social Theory in the Age of the Family (New York: Columbia University Press, 1986), 47-56.

${ }^{61}$ Eldon J. Eisenach, The Lost Promise of Progressivism, 182.

${ }^{62}$ Helen Damon-Moore, Magazines for the Millions, 39.

${ }^{63}$ Cosmopolitan 47 (Oct. 1909): 660; Part 11 (Nov. 1909): 730; Part 111 Cosmopolitan 48 (Dec. 1909): 15;

${ }^{64}$ Jennifer Scanlon, The Ladies' Home Journal, Gender and the Promises of Consumer Culture, 109-35. On Bok's position on women's clubs and his readers' response, see Helen Damon-Moore, Magazines for the Millions, 159-60.

${ }^{65}$ Theda Skocpol, Protecting Soldiers and Sailors, 404; Ida Tarbell, "Why Women Fall into Temptation," LHJ (Nov. 1909); "Man's Inhumanity to Man," American Magazine, 1901; Edith Wyatt, "Working Girls Budgets," McClure's (Feb. 1911).

${ }^{66}$ Richard Schneirov, "Thoughts on Periodizing the Gilded Age: Capital Accumulation, Society, and Politics, 1873-1898," 220-24; James Livingston, Pragmatism, Feminism and Democracy, ch. 3; Currarino, The Labor Question in America, 120-25.

${ }^{67}$ See Ohmann, Selling Culture, 273-75; 283-85. The other books on popular magazines contain no sustained discussion of muckraking.

${ }^{68}$ David Nasaw, The Chief: The Life of William Randolph Hearst (Boston: Houghton Mifflin, 2000), 190201; Matthew Schneirov, The Dream of a New Social Order, 227-43.

${ }^{69}$ On the development of magazine muckraking, see Louis Filler, Crusaders for American Liberalism (Yellow Springs, OH: The Antioch Press, 1939), 9-28; Harold Wilson, McClure's and the Muckrakers, chs. 5 and 7; David Mark Chalmers, The Social and Political Ideas of the Muckrakers (New York: The Citadel Press, 1964), 7-20; Lincoln Steffens, The Autobiography of Lincoln Steffens (New York: Harcourt, Brace and Company, 1931), 357-630. Rising salaries among magazine journalists is discussed in Theodore P. Greene, America's Heroes, 170.

${ }^{70}$ Muckraking articles appeared in many of the Hearst and Pulitzer papers prior to the advent of magazine muckraking. See Richard Schneirov, Labor and Urban Politics, 270-75; Joseph Juergens, Joseph Pulitzer and the New York World (Princeton, NJ: Princeton University Press, 1966); Michael Schudson, Discovering the News: A Social History of American Newspapers (New York: Basic Books, 1978), 88-120.

${ }^{71}$ Louis Filler, Crusaders for American Liberalism; Arthur and Lila Weinberg (eds.), The Muckrakers; The Journalists Who Opened the Public's Eyes to Corruption Everywhere, and Shocked America into an Age of Reform (New York: G.P. Putnam's Sons, 1964), 441-45.

${ }^{72}$ Doris Kearns Goodwin, The Bully Pulpit: Theodore Roosevelt, William Howard Taft, and the Golden Age of Journalism (New York: Simon and Schuster, 2013), 170-202.

${ }^{73}$ Louis Filler, Crusaders for American Liberalism, 180.

${ }^{74}$ Theodore P. Greene, America's Heroes: The Changing Models of Success in American Magazines, 172212.

${ }^{75}$ Alfred Lewis, "Shonts of Isthmus," SEP (Sept. 8, 1906), 15.

${ }^{76}$ Ida Tarbell, "History of Standard Oil" began in McClure's November 1902 issue and ended in McClure's October 1904 issue. It was published in book form in 1904.

${ }^{77}$ Burton Hendrick, "The Story of Life Insurance," McClure's (May 1906).

${ }^{78}$ Lincoln Steffens, Shame of the Cities, appeared in its first installment in McClure's in January 1903, "The Shame of Minneapolis." All the installments were published as a book in 1904 by McClure, Phillips. Also see Lincoln Steffens, The Shame of the Cities (New York, 1957); and Louis Filler, Crusaders for American Liberalism, 90-101; and Matthew Schneirov, The Dream of a New Social Order, 212-21.

${ }^{79}$ David Mark Chalmers, The Social and Political Ideas of the Muckrakers, 75-81; Lincoln Steffens, The Autobiography of Lincoln Steffens.

${ }^{80}$ Meg Jacobs, Pocketbook Politics: Economic Citizenship in the Twentieth Century (Princeton, NJ: Princeton University Press, 2005), 50

${ }^{81}$ David Mark Chalmers, The Social and Political Ideas of the Muckrakers, 88-103; Russell's series on the "beef trust" appeared in Everybody's 12-13 (1905). Also see Charles Elliot Russell, Why I Am A Socialist (New York: Kessinger Publishing, LLC, 1910). 


\section{Matthew Schneirov}

${ }^{82}$ David Mark Chalmers, The Social and Political Ideas of the Muckrakers, 68-71; Harold Wilson, McClure's Magazine and the Muckrakers, 259.

${ }^{83}$ Edward Markham's "The Hoe-Man in the Making” ran in Hearst's Cosmopolitan from September 1906 to June 1907. Alfred Henry Lewis, "Owners of America (Part 1): Andrew Carnegie," Cosmopolitan 45 (June 1908): 3-16. David Graham Phillips, "The Treason of the Senate (Part 1)," Cosmopolitan 40(Mar. 1906): 487-502.

${ }^{84}$ Josiah Flynt, "The Pool Room Vampire and Its Money Mad Victims," Cosmopolitan 42(Feb.1907): 359-71. This article was the first of a five-part series.

${ }^{85}$ On "the language of social bonds," see Daniel T. Rodgers, "In Search of Progressivism," Reviews in American History (Dec. 1982): 113-32.

${ }^{86}$ See Theodore Greene, America's Heroes, Parts 2 and 3.

${ }^{87}$ Ernesto Laclau and Chantal Mouffe, Hegemony and Socialist Strategy: Towards a Radical Democratic Politics, 75-78; Also see Stuart Hall, "Gramsci's Relevance for the Study of Race and Ethnicity," Journal of Communication Inquiry 10(1986): 5-27. For an example of the discourse analysis used here as well as an application of it in understanding the rise of corporate capitalism, see Matthew Schneirov and Richard Schneirov, "Capitalism as a Social Movement: the Corporate and Neoliberal Reconstructions of the American Political Economy in the Twentieth Century," Social Movement Studies 15(2016): 561-76.

${ }^{88}$ Glickman, A Living Wage; Kathy Peiss, Cheap Amusements: Working Women and Leisure in Turn of the Century New Work (Philadelphia: Temple University Press, 1986); Jacobs, Pocketbook Politics.

${ }^{89}$ Martin J. Sklar, The Corporate Reconstruction of American Capitalism, 401-30; Martin J. Sklar, The United States as a Developing Country (Cambridge, UK: Cambridge University Press, 1992), 67-77. Also for an overview of the Progressive Era that insists on its democratic character, see Robert D. Johnston, "ReDemocratizing the Progressive Era: The Politics of Progressive Era Political Historiography," Journal of the Gilded Age and Progressive Era (Jan. 2002): 68-92. 